\title{
ENGLISH LANGUAGE EDUCATIONAL PROGRAM: INNOVATIVE APPROACH TO FORM DEMANDED SPECIALISTS
}

\author{
DOI: $10.31618 /$ ESU.2413-9335.2020.8.73.707 \\ Maria M. Bernstein \\ Ph.D., Associate Professo \\ , Director of MSc. Program "International Management" \\ Institute of Business Studies and Business Administration \\ Russian Presidential Academy \\ of National Economy and Public Administration, \\ Russia, Moscow
}

\section{АНГЛОЯЗЫЧНАЯ ОБРАЗОВАТЕЛЬНАЯ ПРОГРАММА: ИННОВАЦИОННЫЙ ПОДХОД К СОЗДАНИЮ ВОСТРЕБОВАННЫХ СПЕЦИАЛИСТОВ}

\author{
Мария Михайловна Бернштейн \\ к.э.н., доцент кафедры Менеджмента, \\ Директор Магистерской программы «Международный Менеджмент» \\ Института Бизнеса и Делового Администрирования ФГБОУ ВО \\ Российская академия народного хозяйства и государственной \\ службы при Президенте РФ, \\ Москва, Россия.
}

\begin{abstract}
Theoretically analyzed the difficulties and contradictions in education of modern specialists demanded in the sphere of international business. In response to extra-volatile business environment a new Master's degree twoyear educational program was implemented in IBS RANEPA. MSc. "International management" Program is taught completely in English by international faculty for Russian and foreign students. It is aimed at development of professional and soft skills of modern specialists. It gives knowledge and practice to develop students' crosscultural communicative competence. The program has become a basis of creating international teams of businessmen prepared to implement joint projects on emerging and developed markets.
\end{abstract}

Keywords: business education, volatile environment, contradictions, approaches, English language program.

\section{Introduction}

Emerging markets like China, India, Russia, etc. are becoming more and more important for the global economy. Companies that want to penetrate these markets have realized that well worked out strategy can bring tremendous rewards. During the past decade it has become harder to identify the appropriate internationalization strategies and to choose which countries to do business with, as emerging economies pose special challenges for managers.

On the one hand, multinational corporations cannot follow traditionally deployed strategies, which emphasize standardized approaches to new markets sometimes with a few local twists [1]. As a result companies struggle to develop innovative strategies and for this reason they need specialists - flexible and adaptable, with inner gut and real expertise of developing countries to help them navigate these unfamiliar and evolving markets.

On the other hand, companies from developing countries are confidently asserting themselves in the world market and are ready to participate in global competition. The ascendancy of emerging-market firms is evident in rankings such as the Fortune Global 500 and they want to make profit out of advanced markets [2].

No wonder, that according to the international consulting company QS, in the next five years, $60 \%$ of graduates from Chinese business schools will be recruited by transnational corporations directly from the class. That is the reason why, for example, Russian companies continue to give preferences to applicants with a Master's or MBA degree from Western universities.

Volatile business environment of the contemporary world demands new approaches to business problems, strategies of doing business internationally and professional people who are ready to operate in this volatile environment. People are the key to the issue. Who are able to guarantee their readiness?

Research Methodology: Main Problems of business education market

The basis of the research methodology of the problems of business education market is in a comparative study of different approaches to MSc. Educational programs in different business schools.

The analysis of contemporary business education revealed the existence of a typical format of educating managers based mainly on practices and standards of Western companies. It goes without saying that the basic models and fundamental knowledge that are given in international business schools are applicable worldwide. In addition, education in Western business schools is an excellent opportunity for Russian students to master business English, develop intercultural 
communication skills, adopt best practices of doing business and establish business relationships with representatives of global companies.

However, this approach is increasingly being questioned by a number of different people from professors to businessmen, as their experience shows one but significant defect: the acquired Western practical skills are only partially suitable for working in the Russian market, as well as in other emerging markets. Practically, the graduates of foreign programs are not ready to work under conditions of developing countries and have to adapt to the realities of the "domestic" market.

Another fact is noteworthy. According to the research done by McKinsey Global Institute often intense competitive dynamics that can be found in the best performing emerging economies - a competitive mindset that has spawned a new generation of productive and battle-hardened companies, appear to be the reason that aspire to be global champions [2]. And again the question of employment the top management with definite awareness of the appropriate competitive strategy becomes one of the crucial issues of success.

Thus, modern companies require specialists who

-have high level of the English level proficiency as the "lingua franca";

-are familiar with Western practices of doing business and have experience in working abroad;

-are skillful in modern technologies and methods of transforming business processes;

-have knowledge of the realities of business in contemporary emerging markets;

-have experience in successfully implemented strategies on the domestic markets.

So, two main questions exist: what kind of education is sharply needed for successful business development nowadays and where can Russian students gain the required skills and knowledge?

\section{Results of the Research}

Having analyzed the inner situation with Russian Bachelor's Degree graduates (including our Institute of Business Studies) a stable trend was noticed: best students strove to get their Master's Degree abroad not in their Alma Mater. After the studies the majority of them started their carriers abroad. This inner reason was the last straw for our decision on transferring our Russian MSc. Programs to international English Language standards.

According to Begin Group - international company that has been working on educational market since 1999 and specializing in promotion of Russian and foreign educational programs in different countries, less than $16 \%$ of MSc programs in Russia at the moment pose themselves as International, but in reality the majority of them offer foreign students a one-year course of the Russian Language and then teach their Programs in Russian.

In response to the above-mentioned challenges our business school decided to revise the structure and content of the traditional MSc. program that was in usage before 2015 in spite of the fact it was rather successful. An innovative MSc. "International
Management" program of IBS-Moscow RANEPA is created in accordance with the requirements of the Russian Federal Educational Standards and the Bologna standards for Master programs. It has organically combined the international and Russian tracks [3].

\section{Integrative Approach as the Basis of Teaching MSc. Students}

We came to the conclusion that the usage of integrative method of teaching, based on complete combination of special subjects with teaching Business English [4], will make our MSc. Program especially beneficial for Russian as well as foreign students from non-English-speaking countries as it provides opportunities to master the English Language together with learning professional issues. On the one hand, integrative approach to formation of foreign communicative competence provides interconnected mastering of all the components of communicative competence. On the other hand, integrative approach allows teachers modify interdisciplinary links of different subjects making it easier to understand.

The transition to the English language format of teaching the program has allowed IBS-Moscow RANEPA not only to restrain our best graduates from leaving Russia and to increase the number of foreign students within double degree and exchange programs, but also to open a wide recruitment of foreign students to the MSc. "International Management" program.

The Program has become of great interest for Russian students as it gives them opportunities to have all the benefits of Western Business schools, including mastering the Language under the conditions of authentic intercultural communication and possibilities of creating business relationships without moving abroad. For the foreign students their studies give international-rate education and rather valuable experience of living and having practice in business activities in Russian companies.

English Language MSc Program as an Innovative Business Education

We believe that it is not enough nowadays to introduce Case studies and the success stories of the companies from emerging markets into the program. There is a need for a deeper understanding of the essence of the global business processes and their national peculiarities in developing countries that can be achieved by our MSc. Program.

The Program comprises Mandatory Courses, such as Macroeconomic Policy for Emerging Markets, Strategic Marketing (based on the MarkStrat Simulation Platform), Project Management, Innovations EcoSystem Development in VUCAenvironment, Investing and project financing in Emerging Markets, etc.

Also it comprises Interdisciplinary Projects which are aimed at covering the integrated approach to the most important processes in the field of analysis of business strategies. Knowledge in HR, finance, marketing, business legislation and many other subjects helps to find solutions to business problems in international companies, institutions or organizations and evaluate their effectiveness. Thus such courses as 
Big Data \& Business Analytics, Global Strategy Analysis, International Business Law, Corporate Social Responsibility, International Finance, etc. appeared to be not just separate courses but the instruments to solve the whole project. Moreover, performed by small international groups of students projects give the students practice of authentic cooperation.

We consider Soft Skills development as a necessity of the contemporary society that is why we teach the following subjects : Effective Communication and Presentation Skills, Team Building, Personal Development and Career Planning, Strategies and Tactics of Cross-cultural Business Cooperation, etc.

The examples of Elective Courses are: Strategies of Entering New Markets, Cross-Cultural Management, GR and Business in Society, Sales and Distribution Management in Emerging Markets, etc.

In addition to the mentioned above subjects the second-year Master Students have a choice of specializations - individual development tracks: International Entrepreneurship (i.e., Business model innovation: main approaches and topical cases), Alternative Marketing (i.e., Neuro-Marketing, Digital Marketing) and International Finance (i.e., Risk Management, Company Valuation and Company Value Management). These courses include work on projects, participation in Business simulation games and activities.

On the one hand, the course modules that are provided within the program help students develop their knowledge of emerging markets through the study of concepts like economic growth strategies for emerging economies, new business models for emerging markets, the management of international project portfolios, financing new projects, the management of creative and innovative designs, mass media and its global impact, the international business context, marketing for emerging markets, and the varying issues for the development of emerging markets. On the other hand, it is important that students get firsthand experience of life in an emerging economy, gaining specialized knowledge of the Russian business environment and making valuable professional connections in the country.

Our 2-year MSc. Program is taught only in the English language by international team of professors and lecturers from Russia and the world's top universities, consultancies, and multinational companies. It should be especially highlighted that the management principles and techniques students learn during the two-year Program can be applied to any emerging and developed markets, not only the Russian one.

\section{Conclusion}

As a result, the skills that Russian and foreign student of MSc. "International Management" acquire can give our graduates the boost in promotion, finding new opportunities and profitable locations throughout their careers. The Graduates of the program establish international offices for their organization, bring new products to specific markets, or even start completely new business operations from scratch in Russia, other developing and developed countries.
The international track of the program which reveals the approaches of doing business in advanced markets is implemented within the cooperation of business schools of International Business Schools Alliance (IBSA), in which IBS-Moscow is the only representative of the Russian Federation. For 4 years of implementation based on the requests of the educational market, representatives of the real business sphere and the feedbacks from different program graduates, our program has succeeded to work out modules that help the students create ability to work in any markets and be valued and demanded.

The successful experience in cooperation with business schools in Europe and the United States, the worldwide recognition of the high quality of the Master in International Management Program (the program has been included in the TOP-10 of the international rating of the European agency Eduniversal since 2012 even when it was not completely English-speaking) has given the base for further expanding the number of IBS - Moscow RANEPA partners. In 2019 IBS - RANEPA, including the Master of Science International Management Program, was the first and so far the only Russian business school that was given a prestigious AACSB international accreditation.

\section{References}

1.Tarun Khanna, Krishna G. Palepu, Jayant Sinha. Strategies That Fit Emerging Markets. Harvard Business Review. - Issue June 2005.https://hbr.org/2005/06/strategies-that-fit-emergingmarkets

2.Woetzel Jonathan, Madgavkar Anu, Manyika James. The Best-Performing Emerging Economies Emphasize Competition. - Harvard Business Review. September 17, 2018. - https://hbr.org/2018/09/the-bestperforming-emerging-economies-emphasizecompetition

3.Bernstein M. M. (2018) Innovative internationalization strategy: how to gain advantageous skills and knowledge to succeed in the global world. / Bernstein M. // Conference Proceedings, International Reseach Conference "GSOM Emerging Markets Conference - 2018”. - St. Petersburg State University Graduate School of Management, October 4-6 $6^{\text {th }}, 2018$. - pp. $118-120$.

4.Baryshnikov N.V., Bernshteyn V.L. (2018) Formirovanie professional'noi communicativnoi mezhkul'turnoi kompetentsii : obobschenie opyta, poisk metodicheskih resheniy [The Formation of Professional Communicative Cross-cultural Competence: Summarizing the Experience and Searching for New Didactic Solutions]. // Yazyk I kultura [Language and Culture] \# 43. - Tomsk, 2018. pp.136 - 147 .

(C) Maria M. Bernshtein, 2020

Maria M. Bernstein, Ph.D. (Candidate of economic sciences), Associate Professor, Director of MSc. Program "International Management” Institute of Business Studies and Business Administration of the Russian Presidential Academy of National Economy and Public Administration (Moscow, Russia). 